Article

\title{
Regimes of the World (RoW): Opening New Avenues for the Comparative Study of Political Regimes
}

\author{
Anna Lührmann *, Marcus Tannenberg and Staffan I. Lindberg \\ V-Dem Institute, Department of Political Science, University of Gothenburg, 40530 Gothenburg, Sweden; \\ E-Mails: anna.luehrmann@v-dem.net (A.L.), marcus.tannenberg@gu.se (M.T.), xlista@gu.se (S.I.L.) \\ * Corresponding author
}

Submitted: 3 October 2017 | Accepted: 12 January 2018 | Published: 19 March 2018

\begin{abstract}
Classifying political regimes has never been more difficult. Most contemporary regimes hold de-jure multiparty elections with universal suffrage. In some countries, elections ensure that political rulers are-at least somewhat-accountable to the electorate whereas in others they are a mere window dressing exercise for authoritarian politics. Hence, regime types need to be distinguished based on the de-facto implementation of democratic institutions and processes. Using V-Dem data, we propose with Regimes of the World (RoW) such an operationalization of four important regime types-closed and electoral autocracies; electoral and liberal democracies-with vast coverage (almost all countries from 1900 to 2016 ). We also contribute a solution to a fundamental weakness of extant typologies: The unknown extent of misclassification due to uncertainty from measurement error. V-Dem's measures of uncertainty (Bayesian highest posterior densities) allow us to be the first to provide a regime typology that distinguishes cases classified with a high degree of certainty from those with "upper" and "lower" bounds in each category. Finally, a comparison of disagreements with extant datasets (7\%-12\% of the country-years), demonstrates that the RoW classification is more conservative, classifying regimes with electoral manipulation and infringements of the political freedoms more frequently as electoral autocracies, suggesting that it better captures the opaqueness of contemporary autocracies.
\end{abstract}

\section{Keywords}

autocracy; democracy; democratization; regime; typology

Issue

This article is part of the issue "Why Choice Matters: Revisiting and Comparing Measures of Democracy", edited by Heiko Giebler (WZB Berlin Social Science Center, Germany), Saskia P. Ruth (German Institute of Global and Area Studies, Germany), and Dag Tanneberg (University of Potsdam, Germany).

(C) 2018 by the authors; licensee Cogitatio (Lisbon, Portugal). This article is licensed under a Creative Commons Attribution 4.0 International License (CC BY).

\section{Introduction}

Classifying political regimes has never been more difficult. Most regimes in the world hold de-jure multiparty elections with universal suffrage. In some countries, elections ensure that political rulers are-at least somewhat-accountable to the electorate whereas in others they are a mere window dressing exercise for authoritarian politics. Therefore, we need to base regime classification on the de-facto implementation of democratic institutions and processes. This is key to being able to make a meaningful distinction between electoral democracies and electoral autocracies. Such data is provided by the Varieties of Democracy (V-Dem) Project, which covers 177 countries from 1900 to 2016 (Coppedge et al., 2017a, 2017b). While V-Dem primarily provides interval measures, many important research questions require crisp regime measures. For instance, categorical measures of regimes have been used in studies on democracy aid effectiveness (Lührmann, McMann, \& Van Ham, 2017), inquiries of democratic diffusion (Gleditsch \& Ward, 2006), backsliding (Erdmann, 2011), 
sequencing (Wang et al., 2017), characteristics of authoritarian regimes (Schedler, 2013), and regime survival (e.g. Bernhard, Hicken, Reenock, \& Lindberg, 2015; Przeworski, Alvarez, Cheibub, \& Limongi, 2000; Svolik, 2008).

We use the V-Dem data to classify countries into four regime categories. In closed autocracies, the chief executive is either not subjected to elections or there is no meaningful, de-facto competition in elections. Electoral autocracies hold de-facto multiparty elections for the chief executive, but they fall short of democratic standards due to significant irregularities, limitations on party competition or other violations of Dahl's institutional requisites for democracies. To be counted as electoral democracies, countries not only have to hold defacto free and fair and multiparty elections, but alsobased on Robert Dahl's famous articulation of "Polyarchy" as electoral democracy (Coppedge, Lindberg, Skaaning, \& Teorell, 2016; Dahl, 1971, 1998)-achieve a sufficient level of institutional guarantees of democracy such as freedom of association, suffrage, clean elections, an elected executive, and freedom of expression. A liberal democracy is, in addition, characterized by its having effective legislative and judicial oversight of the executive as well as protection of individual liberties and the rule of law.

Although the typology is widely accepted (e.g. Diamond, 2002; Rössler \& Howard, 2009; Schedler, 2013), comprehensive, longitudinal measures have not been available until now. Regimes of the World (RoW) closes this gap by classifying virtually all country-years from 1900 to today based on this typology. In addition, we provide an innovative method to address a key weakness in extant typologies: identifying ambiguous cases close to the thresholds between regime types using V-Dem's measures of uncertainty. This additional information can be integrated into quantitative analyses, for instance by allowing scholars to conduct robustness checks which exclude more ambiguous cases.

Section two discusses prior approaches to regime types while the third section details the RoW typology. Section four compares our regime typology to several of the most frequently used extant measures.

\section{Prior Approaches to Drawing the Line between Regime Types}

Longstanding conceptual and methodological discussions include whether democracy is a best understood as a multidimensional (Coppedge et al., 2011; Dahl, 1971; Vanhanen, 2005), continuous (Bollen \& Jackman, 1989; Lindberg, 2006), polychotomous (Collier \& Levitsky, 1997), or a dichotomous concept (Alvarez, Cheibub, Limongi, \& Przeworski, 1996; Cheibub, Gandhi, \& Vreeland, 2010), as well as debate the precise differentiation between democratic and various types of autocratic regimes (Geddes, Wright, \& Frantz, 2014; Kailitz, 2013;
Wahman, Teorell, \& Hadenius, 2013), including the existence of a "grey zone" (Diamond, 2002). We agree with Collier and Adcock (1999) that the appropriate type of regime measure depends on the nature of the research question at hand. We seek here to provide a robust and comprehensive regime type measure for research requiring an ordinal or a dichotomous measure.

There are two main approaches to conceptualizing and crafting dichotomous measures of democracy and autocracy: as a difference in kind or as a difference in degree, which are associated with qualitative and quantitative approaches to measurement, respectively (Lindberg, 2006, pp. 22-27). The in-kind/qualitative approach typically proceeds in a Sartorian fashion by setting a number of necessary conditions that a regime must fulfill in order to be coded as a democracy. For example, that there are competitive, multiparty elections with suffrage extended to a certain share of the population. The degree/quantitative strand usually introduces a cut-off on a continuous measure of democracy, coding countries above the threshold as democratic and countries below the threshold as being autocratic. In the following, we provide details regarding how six of the most influential datasets on regimes distinguish between democracies and autocracies.

\subsection{In-Kind/Qualitative Approaches}

Cheibub et al. (2010) apply three criteria to distinguish democracies from autocracies: uncertainty, irreversibility, and repeatability. ${ }^{1}$ Operationally, they identify democracies as regimes in which there are, first, more than one legal party; second, a legislature elected by popular elections, and a chief executive that is either directly, or indirectly popularly elected; and finally, an alternation of power must have occurred under the same electoral rules that brought the incumbent into office. While these clear and parsimonious coding rules minimize the need for subjective judgments, they also come at a cost. Two of these criteria raise concerns of conceptual validity. The mere existence of two legal parties hardly guarantees contestation, as understood in established democratic theory (Dahl, 1971), and the alternation rule leads to both type I and type II errors. First, as Wahman (2014) shows, it underestimates the number of democracies since incumbents often enjoy an electoral advantage even in established democracies. Second, even manipulated and un-democratic elections are sometimes lost, which leads to the alternation rule overestimating the number of autocracies (Wahman, 2014, p. 222). These errors have consequences. For example, Knutsen and Wig (2015) demonstrate that the alternation rule leads to the underestimation of democracy's effect on economic growth.

Geddes et al. (2014) sort all cases into either the democratic or autocratic bin (before proceeding to clas-

\footnotetext{
1 Their “Democracy and Dictatorship" dataset builds on earlier work by an overlapping group of authors (Cheibub, Przeworski, Limongi Neto, \& Alvarez, 1996; Przeworski et al., 2000).
} 
sify sub-categories of the latter). They stipulate the following coding rules: a case is coded as democratic if the executive achieves power through "reasonably fair competitive" direct or indirect elections with suffrage exceeding at least $10 \%$ of the population (Geddes, Wright, \& Frantz, 2013, p. 6). This requires a fair amount of judgment by the coder. For example, relying on reports from election observers to determine if an election was reasonably "fair and competitive" can be problematic since such organizations lack shared standards (Kelley, 2009). It is not clear what a "competitive" election or "large" party is by Geddes et al. (2014)'s standards (see Geddes et al., 2013, p. 6), nor is it clear how Geddes et al. (2014) estimate the size of parties which did not enjoy legal rights (Wahman et al., 2013).

Boix, Miller and Rosato (2013) provide a dichotomous measure of democracy/autocracy from 1800 to 2010. Similar to Cheibub et al. (2010) and Geddes et al. (2014), Boix et al. (2013) rely on a set of necessary conditions. For a country to be coded as democratic, the executive must either be directly or indirectly elected in "popular" elections and the legislature in "free and fair" elections. They also require that a majority of the male population has the right to vote. Boix et al. (2013) suffers from a similar weakness as Geddes et al. (2014)-they asses the freedom and fairness of elections without minimizing bias due to the potentially erroneous judgment of the coder.

\subsection{Degree/Quantitative Approaches}

Other scholars apply a threshold on a continuous measure to distinguish between political regimes (Lindberg, 2016; Schedler, 2013; Wahman et al., 2013). The most apparent difficulty with this approach is deciding where to draw the line between democracies and autocracies, which is inevitably, an arbitrary decision (Bogaards, 2012). Even for the most commonly used large- $N$ data sets-Freedom House and Polity-there is no consensus in the literature on where to draw the line. Bogaards (2012) identifies at least 14 different ways to use Freedom House ratings and at least 18 different ways to use the Polity scores to classify democracies.

Freedom House itself uses its political rights and civil liberty scores to label countries as "free", "partly free", and "not free" (Freedom House, 2017). However, this three-level ordinal scale evades the question of which "partly free" country is a democracy and which not. Furthermore, it neglects any necessary conditions-such as free and fair elections-that are commonly found in the literature. Similarly, the Polity project (Marshall, Gurr, \& Jaggers, 2014) provides various detailed assessments of different aspects of regime quality, but refrain from identifying an unambiguous cut-off point between democracy and autocracy. Polity suggests using the com- bined Polity score to cut the regime spectrum into three parts: autocracies ( -10 to -6$)$, democracies (6 to 10), and anocracies, with anocracies being between the first two categories. ${ }^{2}$

Wahman et al. (2013) identify the cut-off point on a combined Freedom House and Polity scale that best represents five qualitative democracy measures, such as the ones we discussed above. They proceed by estimating the mean score on the combined scale for the year before democratic breakdown and the year after transition, as coded by the five measures. They then use the grand mean of seven of these years as their empirical cut-off point for democracy, while advising users to run robustness checks using both the 6.5 and the 7.5 levels.

Scholars addressing the whole regime spectrum have come to distinguish, typically, between closed and electoral autocracies on one hand and liberal and electoral democracies on the other hand (e.g. Diamond, 2002; Rössler \& Howard, 2009; Schedler, 2013) which has become one of the most prolific typologies in the discipline, as well as in the policy-practitioners' world. Nevertheless, we lack comprehensive, longitudinal measures of this four-fold regime typology. ${ }^{3}$ Below, we suggest a way to fill this gap while simultaneously avoiding the weaknesses of the current measures which have been outlined above.

\section{The RoW Typology}

Following this brief review of some of the extant regime typologies, we endeavor to classify regimes into four categories: closed autocracy, electoral autocracy, electoral democracy and liberal democracy (Table 1). First, we separate along the democratic and the autocratic regime spectrum and then develop the democratic and autocratic subtypes. ${ }^{4}$ In a minimalist, Schumpeterian sense, democracies are regimes that hold de-jure multiparty elections. However, many would agree with Pastor $(1999$, p. 123$)$ that "the essence of democratic government is accountability". Such accountability can only evolve if incumbents fear retribution at the ballot box (Mechkova, Lührmann, \& Lindberg, 2017a), and to this end, mere de-jure multiparty elections are not enough (e.g., Levitsky \& Way, 2010; Schedler, 2013). We claim that Dahl's theory of polyarchy $(1971,1998)$ provides the most comprehensive and most widely accepted theory of what distinguishes a democracy based on six (1998, p. 85 -originally p. 8 in his 1971 book) institutional guarantees (elected officials, free and fair elections, freedom of expression, alternative sources of information, associational autonomy, and inclusive citizenship). This conception requires not only free and fair elections but also the freedoms that make them meaningful, and thus avoids the electoral fallacy (Diamond, 2002; Karl, 1986). This allows for demarcation between electoral autocracies and

\footnotetext{
${ }^{2}$ See http://www.systemicpeace.org/polityproject.html

${ }^{3}$ Typically, scholars use data from sources such as Freedom House and/or the Database on Political Institutions, which only starts in the 1970s.

${ }^{4}$ This strategy follows common advice for concept formation (e.g., Collier \& Adcock, 1999, pp. 548-549; Goertz, 2006; Sartori, 1970).
} 
Table 1. Regime classification.

\begin{tabular}{cccc}
\hline Closed Autocracy & Electoral Autocracy & Electoral Democracy & Liberal Democracy \\
\hline $\begin{array}{c}\text { No de-facto multiparty, or free and fair elections, or } \\
\text { Dahl's institutional prerequisites not minimally fulfilled }\end{array}$ & $\begin{array}{c}\text { De-facto multiparty, free and fair elections, and } \\
\text { Dahl's institutional prerequisites minimally fulfilled }\end{array}$ \\
\hline $\begin{array}{cccc}\text { No multiparty elections } & \text { De-jure multiparty elections } \\
\text { for the chief executive } & \text { for the chief executive } & \text { The rule of law, or } & \text { The rule of law, and } \\
\text { or the legislature } & \text { and the legislature } & \text { liberal principles not } & \text { satisfied }\end{array}$ & $\begin{array}{c}\text { libal principles } \\
\text { satisfied }\end{array}$ \\
\hline
\end{tabular}

democracies, unlike minimalist definitions. In short, in democracies rulers are de-facto accountable to citizens through periodic elections and in autocracies they are not. ${ }^{5}$ Therefore, we approach de-facto multiparty and free and fair elections as necessary, qualitative criteria for labelling a regime as a democracy.

We distinguish between electoral democracies that only achieve the basic criteria above, and liberal democracies. We focus on this distinction because it is the most common within the democratic regime spectrum (e.g. Diamond, 1999, 2002; Merkel, 2004; Munck, 2009). In addition to fulfilling the criteria for electoral democracy, liberal democracies are characterized by an additional set of individual and minority rights beyond the electoral sphere, which protect against the "tyranny of the majority"; thus having limits on government is intrinsic to democracy itself (e.g. Dahl, 1956; Hamilton, Madison, \& Jay, 1787/2009; cf. Coppedge, Gerring, Lindberg, Skaaning, \& Teorell, 2017d, p. 21; Lindberg, Coppedge, Gerring, \& Teorell, 2014). This is in Dahl's words "Madisonian" democracy (Dahl, 1956, p. 4). Core components thus include legislative and judicial oversight over the executive providing checks and balances, as well as the protection of individual liberties, including access to, and equality before, the law. In particular, the rule of law is a fundamental prerequisite for the implementation of the liberal principle as it ensures that decisions are implemented (Merkel, 2004).

Autocracies are regimes where rulers are not accountable to citizens by Dahl's standards. The key differences along the authoritarian spectrum are whether the office of the chief executive and seats in the national legislature are subject to direct or indirect multiparty elections (Schedler, 2013, p. 2). In closed autocracies, the chief executive and the legislature are either not subject to elections, or there is no de-facto competition in elections such as in one-party regimes. Regimes with elections that do not affect who is the chief executive (even if somewhat competitive) also fall into this category (following Brownlee, 2009; Donno, 2013; Rössler \& Howard, 2009, p. 112).
In electoral autocracies, on the other hand, the chief executive is dependent on a legislature that is itself elected in de-jure multiparty elections (in parliamentary systems), directly elected alongside a separately elected legislature (in presidential systems), or a combination of both (in semi-presidential systems). In an electoral autocracy, these institutions are de-facto undermined such that electoral accountability is evaded (Diamond, 2002; Gandhi \& Lust-Okar, 2009; Levitsky \& Way, 2010; Schedler, 2002, 2013). They thus fall short of democratic standards due to significant irregularities, limitations on party competition, or other violations of Dahl's institutional requisites. This conceptualization builds on Schedler's influential work on electoral authoritarianism $(2002,2006,2013)$ and the notion of competitive authoritarianism developed by Levitsky and Way (2010).

\subsection{Operationalization with V-Dem Data}

We operationalize the RoW regime typology using data from Varieties of Democracy (V-Dem). ${ }^{6}$ Version 7.1 covers 178 countries from 1900 to 2016 (Coppedge et al., 2017a, 2017b, 2017c; Marquardt \& Pemstein, 2017; Pemstein et al., 2017). Figure 1 portrays the stepwise decision rules. To qualify as an (electoral) democracy, regimes must fulfil three necessary conditions. (1) De-facto multiparty elections as indicated by a score above 2 on the V-Dem indicator for multiparty elections (v2elmulpar_osp); (2) free and fair elections where mistakes and irregularities did not affect the outcome, as indicated by a score above 2 on the respective V-Dem indicator (v2elfrfair_osp); ${ }^{7}$ and (3) following Lindberg (2016, p. 90), a score larger than 0.5 on the V-Dem Electoral Democracy Index (EDI, v2x_polyarchy) which explicitly measures Dahl's institutional de-facto guarantees, based on 41 indicators (Coppedge et al., 2016, 2017a). ${ }^{8}$ The index runs from 0 (not democratic) to 1 (fully democratic).

These coding rules strike a balance between two principles in operationalization: substitutability and necessity. In line with Coppedge et al. (2011), we treat Dahl's list of institutions as partly substitutable. A score larger

\footnotetext{
${ }^{5}$ This reflects the electoral principle of democracy (Coppedge et al., 2016, p. 3).

${ }^{6}$ This operationalization will be included in the V-Dem dataset version 8 under the variable name "v2x_regime" (to be released in Spring 2018 ).

7 The V-Dem measurement model converts expert scores to interval-level point estimates (Pemstein et al., 2017). We use a version of the data in which these interval-level estimates were converted to the original 0-4 scale, which is indicated by the suffix _osp.

${ }^{8}$ The aggregation rule for the EDI allows for one strong sub-component to partially compensate for weaknesses in others, but also penalizes countries weak in one sub-component according to the "weakest link" argument. Thus, the index is formed in one half by the weighted average of its component indices and in the other half by the multiplication of those indices (Coppedge et al., 2016, 2017a).
} 


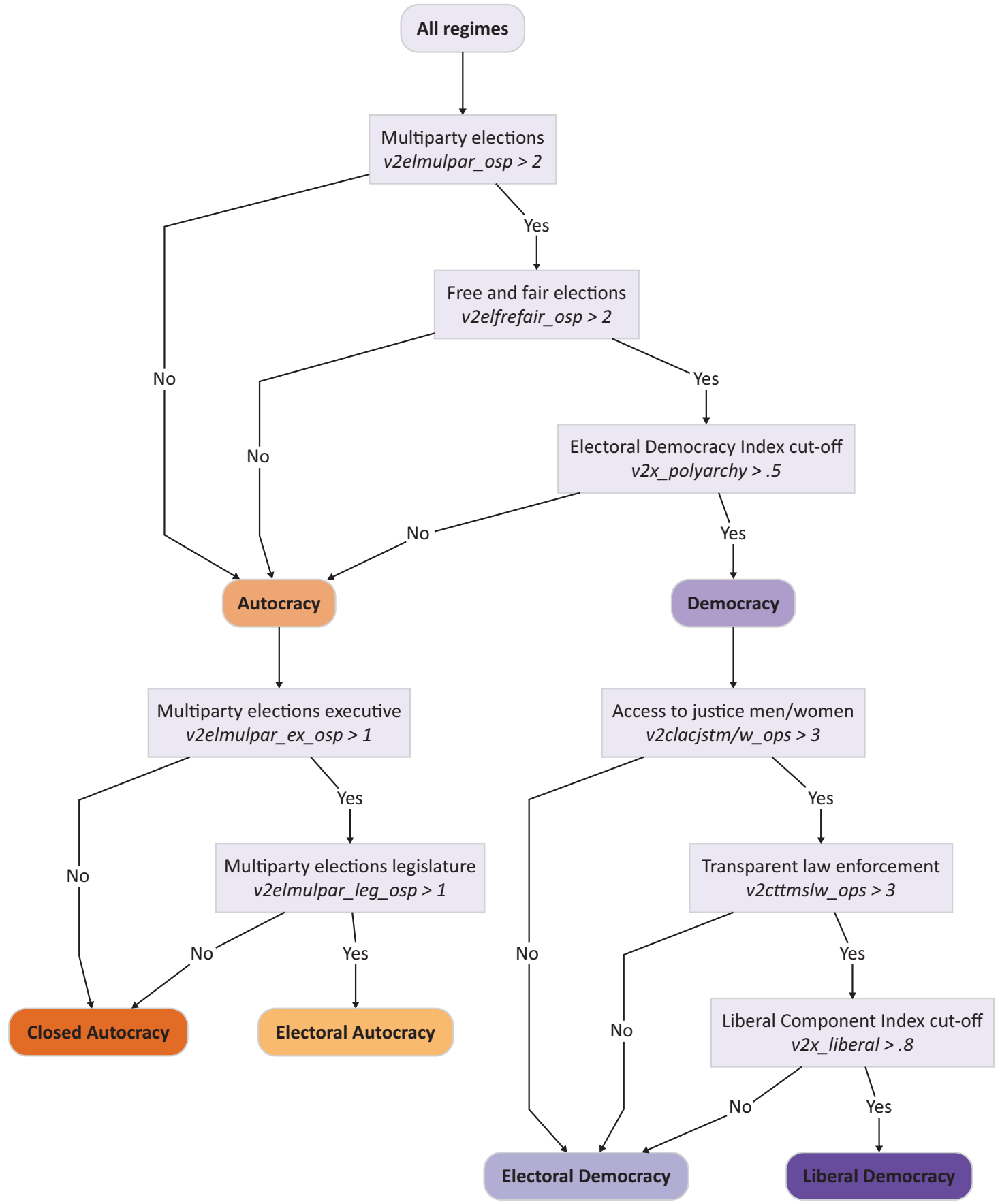

Figure 1. Coding schema for the RoW typologies (for descriptions of variables see Coppedge et al., 2017a).

than 0.5 on the EDI, demonstrates that the balance of potential weaknesses in one area is partly compensated for by strengths in other areas to such a degree that the regime may be classified as being more democratic than not. ${ }^{9}$ Yet, in the conceptualization above, given the aggregation of 41 indicators, it remains possible that a country could reach a level above 0.5 on the index while still lacking two critical aspects: de-facto multiparty elections and the ability of such an election result to be resistant to the effect of irregularities and unintentional mistakes. We approach de-facto free and fair and mul- tiparty elections as necessary conditions. Hence, even while these two indicators are also part of the EDI among the 39 other indicators, we ensure that the-admittedly arbitrary-cut-off point on a continuous scale does not lead to the misclassification of regimes as democracies by combining it with the two key qualitative democracy indicators.

Among dictatorships identified by their failure to meet one or more of the criteria of democracies, electoral autocracies are distinguished from closed dictatorships in that they subject the chief executive to elections

\footnotetext{
${ }^{9}$ For examples underscoring the empirical validity of these cut-off points, see the detailed discussion in section 4.
} 
at least de-jure multiparty competition as indicated by a score above 1 on the applicable V-Dem multiparty elections indicator (v2elmulpar_osp; see Appendix 1).

What distinguishes electoral and liberal democracies is that the latter guarantee the three key aspects of the liberal dimension of democracy discussed above. We operationalize this notion with three necessary criteria. First, liberal democracies need to satisfy three qualitative criteria focusing on the ultimate guarantees of individual liberty: Scores above " 3 " on the V-Dem indicators transparent and predictable law enforcement (v2cltrnslw_osp), and secure and effective access to justice for men (v2clacjstm_osp) and women (v2clacjstw_osp). ${ }^{10}$ While the non-arbitrary enforcement of laws is a prerequisite for the implementation of rules in the first place, access to justice gives individuals the chance to challenge arbitrary enforcement patterns (Botero \& Ponce, 2011). In order to further guarantee that no country is undeservedly classified as a liberal democracy, we require a liberal democracy to overall satisfy the liberal principles of respect for personal liberties and the rule of law, and judicial as well as legislative constraints on the executive, as indicated by a score above 0.8 on the summary V-Dem Liberal Component Index (v2x_liberal). ${ }^{11}$ Corresponding to the distinction between democracies and autocracies, the inclusion of an aggregated index in the operationalization rules allows for the substitution of weaknesses in one area with strength in others. The threshold is naturally arbitrary but setting it high, at the upper quartile of the scale, seeks to ensure that the criterion adheres to the fairly strict demands expressed in the literature in the liberal tradition.

\subsection{Accounting for Ambiguity: Lower and Upper Bounds of Regime Categories}

A principal objection leveraged against quantitative approaches to measuring regime types is that countries close to thresholds between categories may be misclassified due to measurement error and uncertainty (e.g. Boix et al., 2013). However, qualitative approaches face the same issue (e.g. Alvarez et al., 1996). The only difference is that we do not know how close or far away a case if from the threshold since they are based on assessments of-often individual-coders with unknown thresholds and unreported uncertainty. The thresholds in quantitative approaches are often more transparent and the consequences of varying them can be tested (Lindberg, 2016, p. 81), but without confidence intervals around point estimates, we still do not know which cases may be misclassified regardless of threshold.

We suggest a major advance on current categorizations in this regard by incorporating into the RoW typology "grey-zone" categories of ambiguously classified cases as indicated by confidence intervals from the underlying Bayesian aggregation methods. ${ }^{12}$ The V-Dem dataset provides not only point estimates for indices and variables but also demarcates the interval in which $\mathrm{V}$ Dem's custom-designed Bayesian item-response theory measurement model places $68 \%$ of the probability mass for each country-year score. These are calculated slightly different at the indicator and index-level but provide the rough equivalent of one standard deviation confidence interval on either side of the points estimates. ${ }^{13}$

We use these intervals to identify cases that are close to the thresholds between categories, those which are ambiguously classified. If the V-Dem Bayesian highest posterior density interval for an indicator or an index used for the categorization into the four main regime types, overlaps with the threshold of an adjacent category, then the case is classified as ambiguous.

For example, Macedonia's score on the EDI was 0.53 in 2016, slightly above the threshold for electoral democracy $(0.5)$. The values for the two qualitative criteria for elections (multiparty, 3.9; and free and fair, 3.0) are also above the thresholds electoral democracy. However, the lower bound of the EDI score (v2x_polyarchy_codelow) for Macedonia is 0.48 and thus falls within the range of electoral autocracy. Hence, in the RoW typology, we label the country as being "Electoral Democracy Lower Bound", to reflect this ambiguity. Our classification is corroborated by credible reports that freedom of expression has been restricted in Macedonia in recent years. ${ }^{14}$

\footnotetext{
10 In an earlier version of this article (and in the V-Dem Data Set v7), we did not include these additional qualitative criteria for liberal democracies. As a consequence, some countries with dubious respect for liberal principles met the threshold for liberal democracies (e.g. Hungary and Tunisia in 2016; the United States prior to the improvements in civil rights in 1968). In order to make our measure of liberal democracy a more ambitious reflection of democratic "completeness" - to borrow from Welzel (2013, p. 255)-we opted to include additional criteria.

11 This index gives the average of following indices on a scale from 0 (not at all satisfied) to 1 (satisfied): equality before the law and individual liberties (v2xcl_rol), judicial constraints on the executive (v2x_jucon), and legislative constraints on the executive (v2xlg_legcon) (Coppedge et al., 2017a, p. 47).

12 This operationalization is included in the V-Dem Data Set v8 under the variable name "v2x_regime_amb" (to be released in Spring 2018). We are grateful to Valeriya Mechkova for suggesting this approach to using the Bayesian highest posterior density intervals.

13 For each indicator, V-Dem provides upper and lower bound estimates, which represent $68 \%$ of the highest posterior densities (distribution mass), i.e., a range of most probable values for a given observation. The intervals increase with the degree of ambiguity in the raw, expert-coded data. At the indicator-level, mainly three factors influence the size of the intervals: high levels of disagreement between expert coders, a low number of coders, and the presence of coders with relatively low estimated reliability (i.e., high stochastic error variance). V-Dem uses Bayesian Factor Analysis (BFAs implemented with the R package MCMCpack) to aggregate indicators to mid-level indices, such as the Clean Election Index. In the BFA framework, the size of the area covered by the 68 highest posterior densities of mid-level indices increases in size if underlying indicators show low levels of correlation. The BFAs are run over 900 posterior draws from the indicators. As a result, uncertainty about indicators also influences the size of the interval in which the modeling places $68 \%$ of the probability mass of the mid-level indices. Similar logic applies for top-level indices (such as the Electoral Democracy Index, and the Liberal Component Index), which combine several mid-level indices (Marquardt \& Pemstein, 2017; Pemstein et al., 2017).

14 On the recent developments in Macedonia see BBC (http://www.bbc.com/news/world-europe-36031417) and the European Digital Rights Association (https://edri.org/huge-protest-against-corruption-surveillance-in-macedonia).
} 
Similarly, Poland lost its status as a liberal democracy in 2013 when the point estimate for one of the qualitative indicators (the transparent law enforcement indicator; v2cltrnslw_osp) dropped below the threshold of 3.0, while the upper bound remains above the threshold. It is therefore classified as an "Electoral Democracy Upper Bound".

The RoW typology thus represents a more transparent ordinal measure of regime types than prior approaches, reflecting the estimates of uncertainty of the underlying data calculated by state-of-the-art Bayesian models. We argue that this is a major advance on extant regime typologies-quantitative or qualitative-which do not report how certain we should be about each classification. This brings together conceptual validity and precision with transparent and systematic incorporation of uncertainty with four "pure" regime types and six upper and lower bound regime categories.

\section{Opening New Perspectives in Regime Studies}

RoW also provides us with unique opportunities to answer new questions. For example, we can analyse changes over time with regard to the share of countries in these grey zones between the "pure" regime types. Figure 2 demonstrates that almost all countries were unambiguously classified at the beginning of the last century (light-grey line on top of the graph). The level of ambiguity (black dashed line) started increasing from around 1960 and peaked during the 1990s-coinciding with the height of the third wave of democratization identified by Huntington (1992). By 2016, almost $30 \%$ of all countries were in one of the ambiguous categories, and $12 \%$ fell in the critical grey zone between democracy and autocracy. This is a significant result in itself.
There are two but distinct developments driving this trend. First, an increasing number of countries are in the ambiguous regime categories because they have de-jure democratic institutions, but simultaneously undermine their effectiveness. The share of unambiguous regimes dropped from above $94 \%$ in 1950 to $70 \%$ in 2016 . Second, the average distance between the upper and lower bounds of the V-Dem indicators and indices have increased in recent decades, reflecting among other things greater disagreement among coders. This also suggests that it has become harder to unambiguously assess countries' states of affairs, even on the very discreet issues that V-Dem ask country experts to rate. The world is becoming opaquer in terms of regimes.

Figure 3 shows the development over time of the RoW regime types (tinted colors indicate ambiguous categories). Our data allow us to show how the number of regimes in the ambiguous categories has increased over recent decades. Several commentators have also recently expressed concerns about potential backsliding among liberal democracies. This is captured in the RoW measure with the number of liberal democracies declining in the last few years. Furthermore, we can identify two pronounced developments associated with the second half of the third wave of democratization, from around 1990. First, the two intermediate categories between electoral democracies and autocracies have both grown wider. Second, the number of closed autocracies declined sharply. Electoral autocracies and electoral democracies have replaced this regime type. An important implication of these two developments is that an increasingly greater number of countries risk being misclassified by extant measures, thus opening the spectre of biased, or even misleading results. RoW can help us solve that problem.

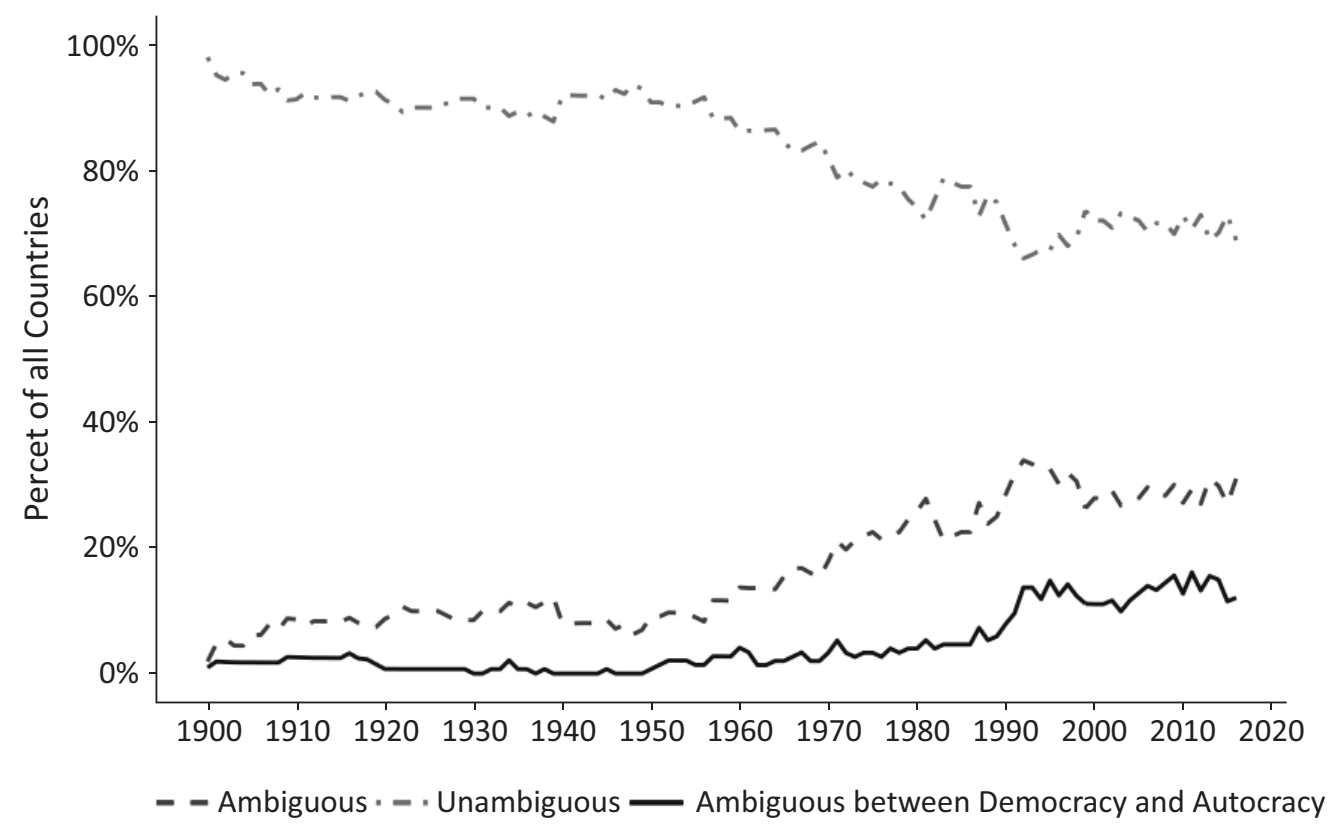

Figure 2. The development of regime ambiguity in the world from 1900 to today. 


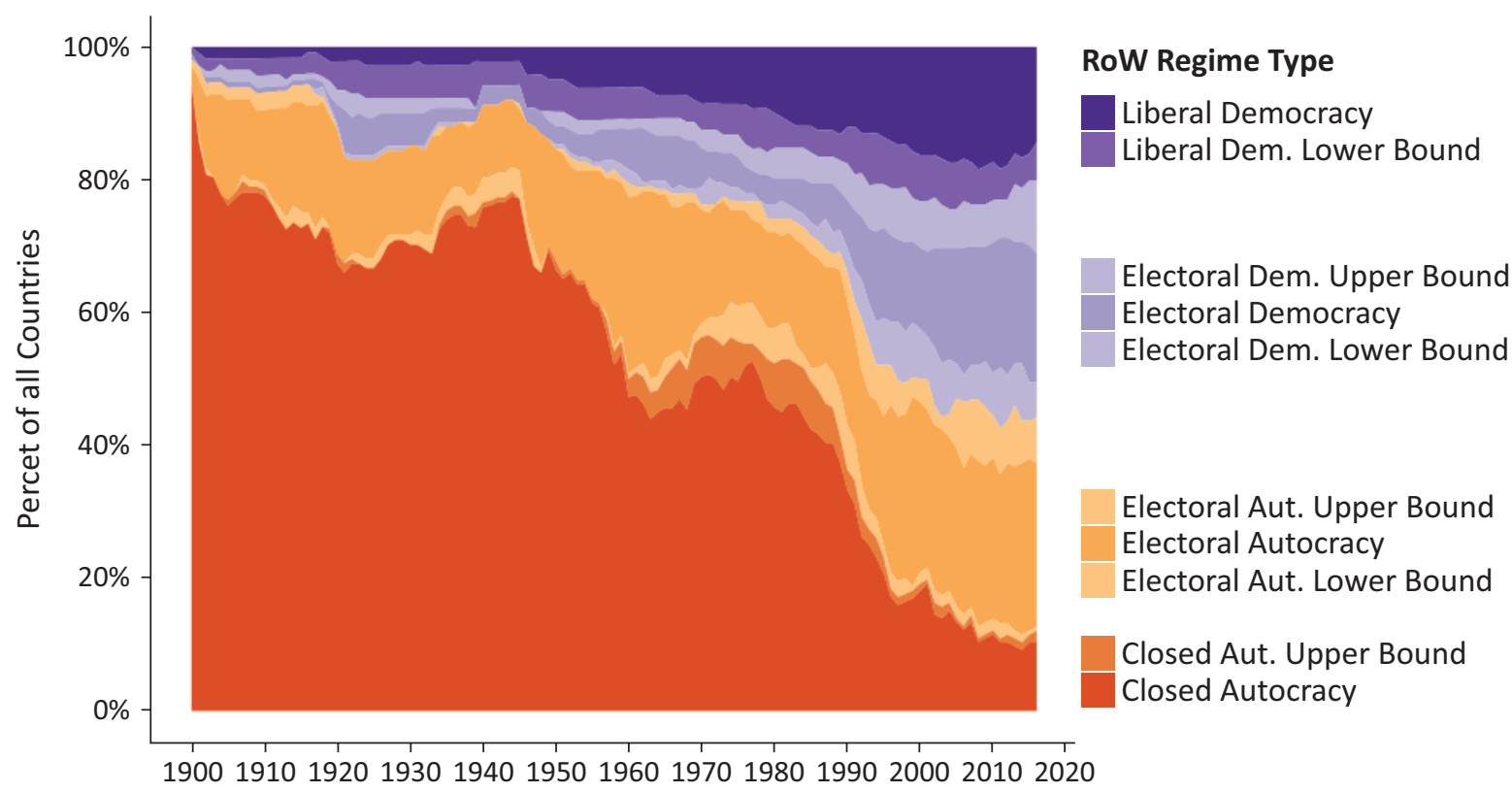

Figure 3. Regimes of the World (RoW) 1900-2016. Source: Coppedge et al. (2017b).

In addition to such descriptive analysis, we recommend the use of ambiguous categories for robustness checks in quantitative analysis. For instance, in democratic survival analyses it makes sense to repeat the analysis varying the in- and exclusion of the ambiguous cases from both the democratic and autocratic regime categories.

\section{Comparing RoW to Dichotomous Measures of Democracy}

The distinction between democracy and autocracy is arguably the most important aspect of a regime typology.
The RoW typology lends itself also to research that requires a dichotomous measure since both the two categories of democracy and autocracy can be collapsed. The lower bounds of (electoral) democracy and the upper bounds of (electoral) autocracy still apply and can be used in combination with the pure regime types in the same fashion as discussed above. In this section, we compare RoW's distinction between democracy and autocracy to the most relevant extant measures, namely those provided by Boix et al. (2013), Cheibub et al. (2010), and Geddes et al. (2014); and Freedom House (Freedom House, 2017), Polity (Marshall et al., 2014), and Wahman et al. (2013).

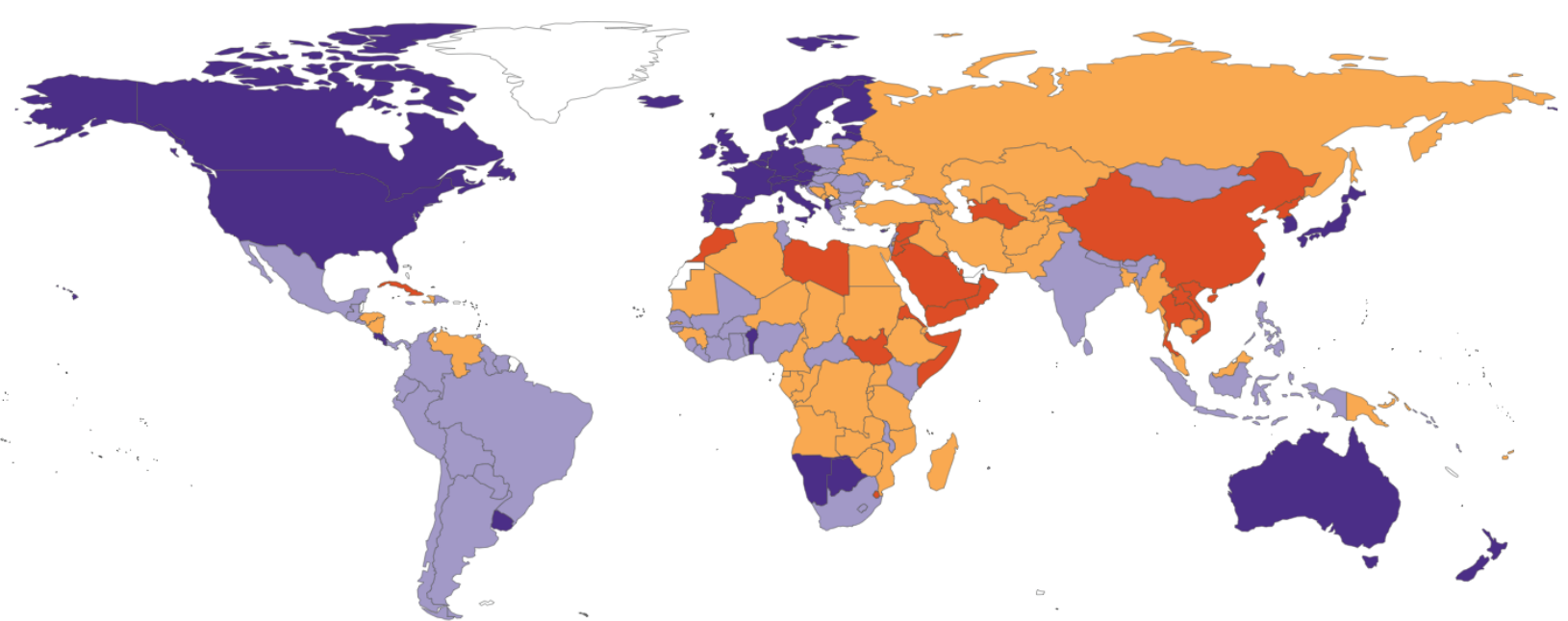

RoW Regime Type

Closed Autocracy

Electoral Autocracy
Electoral Democracy

Liberal Democracy

Figure 4. Regimes of the World (RoW) 2016. Source: Coppedge et al. (2017b). 
The purpose of this appraisal is two-fold: First, it helps to assess the convergent validity of the RoW measure, one of the most commonly used strategies for new regime type measures (Adcock \& Collier, 2001, p. 540). Second, and in line with the spirit of this thematic issue, we seek to make clear what the empirical consequences of the measurement choices are for users of the RoW typology.

A comparison with extant measures, unfortunately, means we have to disregard the ambiguous and pure regime classifications in the RoW measure. Figure 3 first illustrates the distribution of regime types in the world in 2016. Most regimes are in the democratic spectrum (56\%): 62 countries qualify as electoral democracies and 35 as liberal democracies (of 174 countries). 56 countries $(32 \%)$ are electoral autocracies and 21 (12\%) are closed autocracies. For a complete list see Appendix 2.

Table 2 compares RoW to the most commonly used measures in the literature. One striking difference is the coverage of RoW, which is matched only by Boix et al. (2013) and Polity, in that it includes all countries and semi-independent territories (including most colonies) from 1900 until the present, and will continue to be updated annually. Cheibub et al. (2010) and Geddes et al. (2014) start in 1946, Wahman et al. (2013) in 1970 and none of them provide data after 2010. While Boix et al. (2013) starts in 1800, it is not updated so the last seven years are not covered. Polity has a longer time series and is updated annually but does not cover semiindependent countries and territories. The fourth column shows that the rate of agreement is relatively high, varying between $88.5 \%$ (Cheibub et al., 2010) and 93.1\% (Wahman et al., 2013). Excluding the cases which our typology qualifies as ambiguous, the level of agreement varies between $91.7 \%$ (Cheibub et al., 2010) and 93.5\% (Geddes et al., 2014). When there is disagreement between RoW and other measures, our classification tends to be more conservative and sets a higher bar for what counts as a democracy, i.e., by classifying certain countries as autocracies whereas others place them in the democratic regime spectrum.

The four different panels in Figure 5 display the RoW count of democracies over time compared with the other measures. Three other measures have data prior to 1970-Boix et al. (2013), Cheibub et al. (2010), and Geddes et al. (2014).

The overlap of observations between our RoW measure with Boix et al. (2013) $(11,262$ cases) is the second largest, with a rate of agreement on classification in $90.8 \%$ of these observations (Figure 5 [A]). The level of agreement increases to $93.5 \%$ if we exclude observations that fall into the ambiguous categories according to RoW. In general, Boix et al. (2013) has a lower threshold for democracy: $84 \%$ of disagreements on the classification of country-years are due to Boix et al. (2013) classifying them as democracies while they are coded as autocracies by RoW. For example, Boix et al. (2013) code Chile between 1909 and 1949 as democratic even though only 25 to $35 \%$ of the adult population were enfranchized due to a lack of female suffrage. Another example is Guatemala, which Boix et al. (2013) and Cheibub et al. (2010) code as democratic following the general election in 1958 up until the onset of civil war in 1981. RoW classifies it as an electoral autocracy. We think the RoW classification has greater face validity since it captures the absence of de-facto minimum level of institutional requirements of democracy in this case: Illiterate women were banned from voting up until 1966 (Organi-

Table 2. Comparison of six dichotomous measures to the RoW democracy threshold.

\begin{tabular}{|c|c|c|c|c|c|c|}
\hline & $\begin{array}{l}\text { Country } \\
\text { Years }\end{array}$ & Coverage & $\begin{array}{c}\text { Country-Year } \\
\text { Overlap with Row }\end{array}$ & $\begin{array}{c}\text { Agree with } \\
\text { Row }\end{array}$ & $\begin{array}{l}\text { RoW Autocracy } \\
\text { Other Democracy }\end{array}$ & $\begin{array}{l}\text { Row Democracy } \\
\text { Other Autocracy }\end{array}$ \\
\hline RoW & 17140 & 1900-2016 & & & & \\
\hline Boix et al. (2013) & 16988 & 1800-2010 & 11,262 & $\begin{array}{c}90.8 \% \\
(93.5 \%)\end{array}$ & $\begin{array}{l}7.7 \% \\
(5.8 \%)\end{array}$ & $\begin{array}{c}1.5 \% \\
(0.7 \%)\end{array}$ \\
\hline Polity & 16826 & 1800-2016 & 11,394 & $\begin{array}{c}92.1 \% \\
(94.3 \%)\end{array}$ & $\begin{array}{l}5.4 \% \\
(4.1 \%)\end{array}$ & $\begin{array}{c}2.5 \% \\
(1.6 \%)\end{array}$ \\
\hline Cheibub et al. (2010) & 9117 & 1946-2008 & 8,187 & $\begin{array}{c}88.5 \% \\
(91.7 \%)\end{array}$ & $\begin{array}{l}8.5 \% \\
(6.4 \%)\end{array}$ & $\begin{array}{c}2.9 \% \\
(1.9 \%)\end{array}$ \\
\hline Geddes et al. (2014) & 7956 & 1946-2010 & 7,688 & $\begin{array}{c}90.2 \% \\
(92.8 \%)\end{array}$ & $\begin{array}{l}7.4 \% \\
(5.7 \%)\end{array}$ & $\begin{array}{c}2.4 \% \\
(1.4 \%)\end{array}$ \\
\hline Wahman et al. (2013) & 6279 & $1970-2010$ & 6,277 & $\begin{array}{c}93.1 \% \\
(96.8 \%)\end{array}$ & $\begin{array}{c}2.8 \% \\
(1.3 \%)\end{array}$ & $\begin{array}{c}4.0 \% \\
(1.9 \%)\end{array}$ \\
\hline Freedom House & 6277 & 1973-2016 & 6,275 & $\begin{array}{c}88.8 \% \\
(93.3 \%)\end{array}$ & $\begin{array}{c}1.7 \% \\
(0.9 \%)\end{array}$ & $\begin{array}{c}9.6 \% \\
(4.6 \%)\end{array}$ \\
\hline
\end{tabular}

Note: Numbers in brackets are calculated excluding the cases we identified as ambiguous (see section 2). Source: RoW, Coppedge et al. (2017b); Boix et al. (2013); Cheibub et al. (2010); Geddes et al. (2014); Freedom House (2017), Polity (Marshall et al., 2014) and Wahman et al. (2013). 

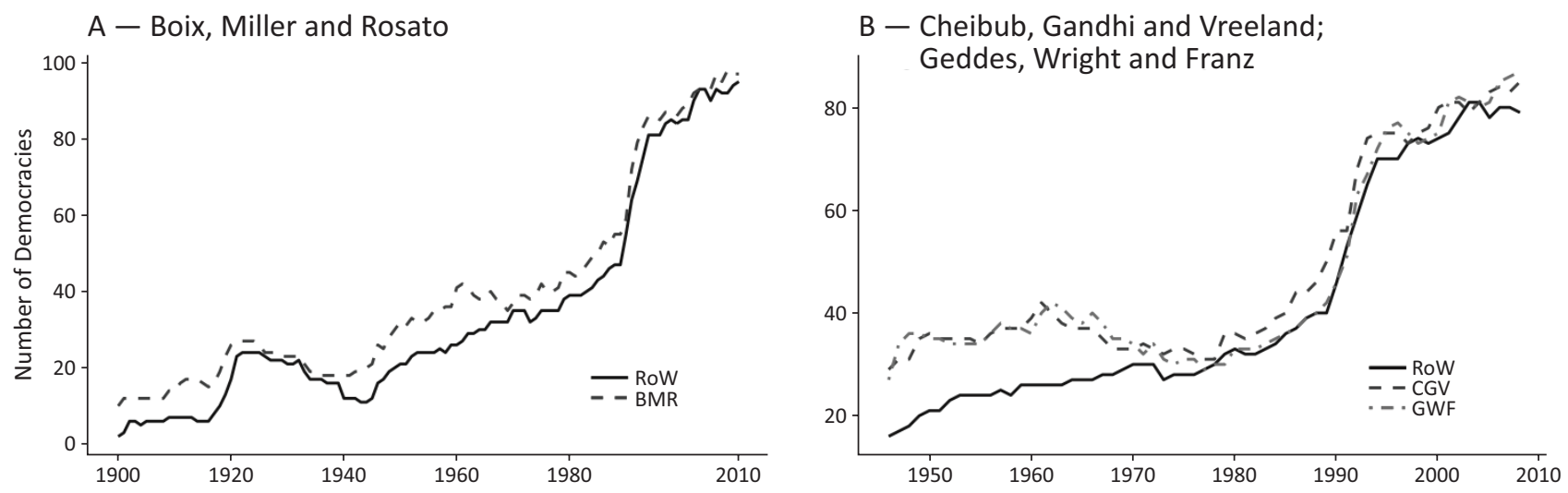

C - Wahman, Teorell and Hadenius
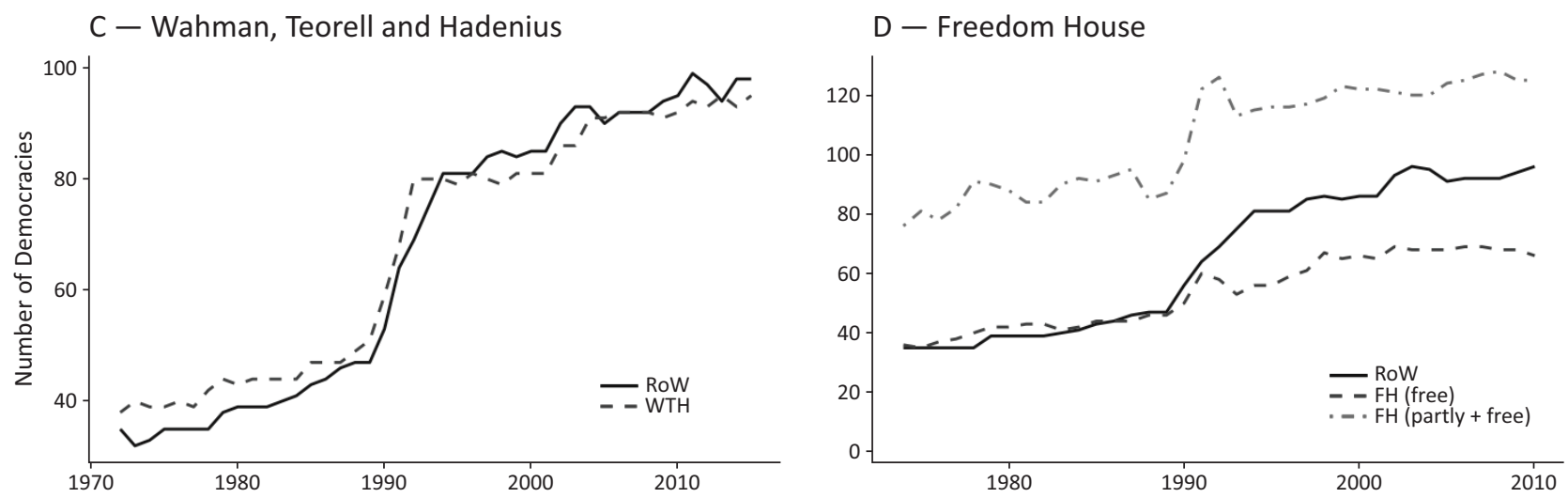

Figure 5. Visual comparison of other measures to RoW. Note: Each panel is limited to the time period and cases of the dataset with least coverage.

zation of American States, 2008), and parties faced severe obstacles to establish themselves and to their participation in elections. Furthermore, electoral intimidation was common throughout the period, and civil society organizations were not free to form or operate. Boix et al. (2013) also codes Czechoslovakia (1939-1945), Norway, Belgium, the Netherlands (1940-1945), and Denmark (1943-1944), as democratic during the years of German occupation whereas RoW does not. Out of the few Boix et al. (2013) autocracies that are coded as democracies in RoW, half are classified as ambiguous cases. Among the unambiguous democracies, RoW captures the dramatic shift from an absolute monarchy to democracy that took place in Bhutan following its first parliamentary elections in $2007 / 2008$, and coded the country as being democratic from 2009 onwards. This is in line with case study evidence (Turner \& Tshering, 2014).

Cheibub et al. (2010) provide regime classifications for 9,117 country-years; 8,187 observations overlap with RoW, and the rate of agreement is $88.5 \%$ (Figure $5[\mathrm{~B}]$ ). ${ }^{15}$ Out of the 933 disagreements, $75 \%(N=696)$ are country-years that Cheibub et al. (2010) code as democratic and RoW classifies as autocratic. This discrepancy may be due to Cheibub et al. (2010) using a lower threshold for democracy than RoW. For instance, Cheibub et al. (2010) classifies Kyrgyzstan (2005-2008) and Armenia (1995-2008) as democracies whereas the V-Dem expertcoded de-facto indicators capture severe shortcomings in terms of the most basic requirements of democracy such as the freedom and fairness of elections. When RoW classifies countries as democracies which Cheibub et al. (2010) codes as autocratic, it is due to Cheibub et al. (2010)'s controversial alternation rule. For example, Botswana, South Africa, and Namibia are autocracies according to Cheibub et al. (2010) for all years covered, because only one party has been in power since the introduction of multi-party elections. The V-Dem indicators build on indicators that do not require alternation in power, leading to their classification as liberal democracies in the late 1990s. This result is in line with the conclusions of prominent observers (e.g., Diamond, 1999, pp. ix-xxvi).

The RoW measure covers all but 168 of Geddes et al. (2014)'s 7,956 observations, ${ }^{16}$ and out of the overlapping country years, the level of agreement of the two measures is $90.2 \%$ (92.8\% excluding ambiguous cases).

\footnotetext{
15 Cheibub et al. (2010) cover 973 observations that are not in the RoW measure. These are mainly microstates not included in the V-Dem Data set: Luxemburg; Andorra, Antigua and Barbuda, Bahamas, Bahrain, Belize; Brunei; Grenada; Kiribati; Lichtenstein; Malta; Marshall Island; Micronesia; Nauru; Palau; Samoa; San Marino; St. Kitts and Nevis; St. Lucia; St. Vincent and the Grenadines; Tonga; Tuvalu; United Arab Emirates. Additionally, Cheibub et al. (2010) covers Oman 1970-1999; Cameroon 1961-1963; and Mozambique 1975-1977, which are not included in V-Dem.

16 These are the two small states Luxemburg and United Arab Emirates and individual years in Oman (1946-1999), Cameroon (1961-1963), and Mozambique (1976-1977), which are not included in the V-Dem data.
} 
The measures diverge in particular prior to the 1970s and in the early 2000s. Again, when classifying a country as democratic, RoW is more demanding than Geddes et al. (2014) (Figure 5 [B]). For example, Geddes et al. (2014) code Sierra Leone (1999-2002) as democratic even though the then ongoing civil war drastically undermined rules and procedures (Harris, 2014). Similarly, they rate the Central African Republic (1993-2003), Burundi (2005-2010), and Nepal (1991-2002) as democratic, whereas V-Dem's expert-based indicators indicate severe violations or grave deficiencies in the institutional requisites of democracy. In contrast, a number of countries in which V-Dem experts report relatively strong democratic institutions, both de-jure and de-facto, are coded as autocracies by Geddes et al. (2014): Botswana (1967-2010), Burkina Faso (1993-2010), Ghana (19962000), Namibia (1991-2010), and Senegal (1983-2000). The V-Dem coding is consistent with academic assessments of the state of democracy in Ghana (Abdulai \& Crawford, 2010), Botswana and Namibia (Diamond, 1999), although some observers of Senegal denote the time period as one of "transition to a fully democratic state" and prefer to label the country as "semidemocratic" (Coulon, 1988; Vengroff, 1993, p. 23). RoW reflects this ambiguity, classifying Senegal as an unambiguous democracy only after the improvements following the 1993 election.

RoW covers all observations in the Wahman et al. (2013) data set with the exception of Mozambique from 1975-1977. Out of all measures compared in this article, Wahman et al. (2013)'s has the highest level of concordance with RoW (Figure 5 [C]; 93.1\% or $96.8 \%$ excluding ambiguous cases). Wahman et al. (2013) is based on the Freedom House and Polity ratings (see discussion in section 1). When defining only countries that Freedom House codes "free" as democracies the agreement falls to $88.8 \%$ or $93.3 \%$ when excluding the cases classified as ambiguous in RoW (see Figure 5 [D]). The bulk of the disagreements stem from countries that we classify as democracies but that are "partly free" according to Freedom House. However, lowering the dichotomous threshold to include all "partly free" countries as democracies reduces the concordance to $75.5 \%$, indicating that a majority of countries that Freedom House code as partly free are coded as autocracies in RoW. Hence, overall the agreement between the RoW and Wahman et al. (2013) datasets is greater than when comparing RoW to either Freedom House or Polity separately.

Polity IV is the data source with the greatest number of country-years overlapping with RoW $(11,394)$. Following Marshall et al. (2014)'s suggestion to treat countries above and equal to 6 on the combined Polity scale as democracies, classification agreement with RoW is $92.1 \%$, or $94.3 \%$ when excluding ambiguous cases. Most disagreements are once again due to RoW autocracies being coded as democracies in Polity. For example, Polity codes Sweden (1916-1919) and the United States (1900-1919) as perfect democracies (score 10) when women were disenfranchised. RoW classifies these cases as electoral autocracies. In recent years, Burundi (2005-2013), Malawi (1994-2013), and Malaysia (20082012) are democracies according to Polity while V-Dem experts observe severe obstacles to democracy. There are also disagreements of other sorts. For example, while Polity codes Suriname as just short of being a democracy (score of 5) since 1991, V-Dem's indicators rate the country as a liberal democracy for the same time period. Figure 6 shows the share of countries coded as RoW democracies for each value on the combined Polity scale. In general, higher values on the Polity scale correspond to a higher share of RoW democracies. The spike in the polity score of 0 is driven by Burkina Faso (2001-2014) and Uruguay (1939-1951), which are classified as democracies in RoW. According to V-Dem coders Burkina Faso had

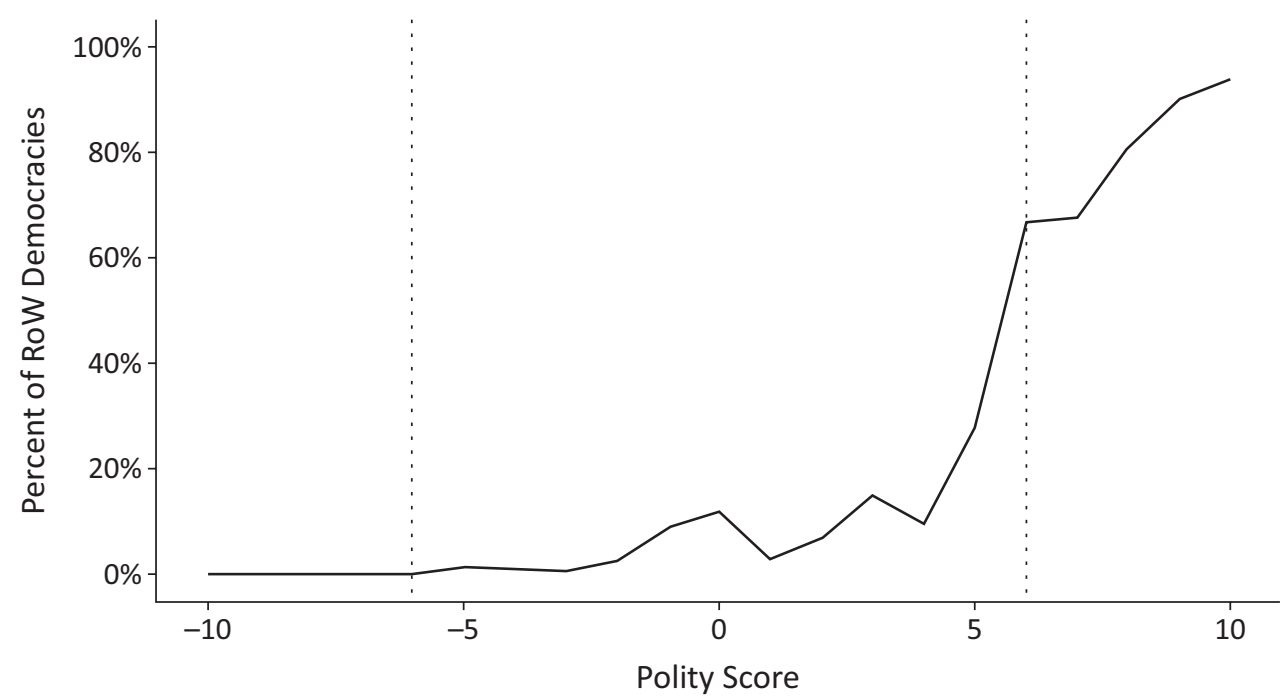

Figure 6. Percentage of RoW democracies by Polity score. Note: The dotted vertical lines mark Polity's suggested thresholds of autocracy $(\leq-6)$ and democracy $(\geq 6)$, with anocracy in between (Marshall et al., 2014). Cases of foreign interruption, interregnum or anarchy, and transitions (polity codes: $-66,-77$, and -88 ) are excluded from this comparison. 
relatively strong democratic institutions, both de-jure and de-facto during those years. While Uruguay did not guarantee full political freedoms in the first three years following the dictatorship of Gabriel Terra (1933-1938), the country can indeed be considered a democracy following the introduction of its new constitution in 1942. Similarly, the relatively high value of -1 on the Polity scale is driven largely by Senegal (1983-2000), which according to V-Dem coders had both de-jure and de-facto democratic institutions.

Overall the new Row typology relatively closely tracks the classification of country-years as either democratic or autocratic by major extant binary measures of democracy. This is a good sign of convergent validity. However, there are substantial differences concerning a significant number of cases, primarily where de-facto practices deviate from de-jure standards. We argue that the RoW typology does a better job than others in these instances, discriminating "real" from "fake" democracies.

For example, most other measures code Kenya as democratic ${ }^{17}$ in the years following the crisis that erupted after president Kibaki was accused of stealing the December 2007 election (Rutten \& Owuor, 2009). Politically-motivated (Kagwanja \& Southall, 2009)and allegedly state-sponsored-violence left more than 1,000 people dead and up to 500,000 people displaced (Human Rights Watch, 2008). RoW picks up this political turbulence, with Kenya being classified as autocratic from 2007 until the freer and fairer elections of 2013. While Cheibub et al. (2010), Geddes et al. (2014), and Boix et al. (2013) code Sri Lanka as democratic between 2005 and 2009, RoW captures the limitations to democracy that existed before and during the 2008/2009 civil war and classify it as autocratic. Similarly, Cheibub et al. (2010), Geddes et al. (2014), Boix et al. (2013), and Polity code Burundi as democratic following the presidential election of 2005, whereas RoW classifies Burundi as autocratic reflecting, among other things, that there was no de-facto multiparty competition and president Nkurunziza ran unopposed. RoW also categorizes Nigeria as an electoral autocracy prior to 2011, a reflection of the widespread electoral manipulation that marred all Nigerian elections until 2011 (Lewis, 2011), whereas Cheibub et al. (2010) and Geddes et al. (2014) classify Nigeria as a democracy from 2000. While Polity, Freedom House and Wahman et al. (2013) also place Nigeria on the autocratic spectrum prior to 2011, the democratic improvements in 2011 are not noted in their coding, which is static up until 2015. Another example is Albania, which Boix et al. (2013), Cheibub et al. (2010), and Geddes et al. (2014) code as democratic from 1991 or 1992 and onwards even though the main opposition leader Fatos Nano was jailed from 1993 to 1999 on politically motivated charges (Abrahams, 1996). In contrast, RoW codes Albania as democratic only from 2002 onwards.

Many fewer country-years are classified as democracies in RoW when most or all other measures code them as autocratic. This applies for example to Namibia (19912010) where free and fair multiparty elections in combination with freedom of expression and association qualify Namibia as a democracy based on the assessment of the V-Dem experts, whereas most other data sets (Boix et al., 2013; Cheibub et al., 2010; Geddes et al., 2014; and Polity) disagree. In line with RoW, Freedom House classifies Namibia as "free" from the 1990's onwards, and Larry Diamond (1999) describes it as a "liberal democracy". Similar disagreement can be observed for Zambia (1994-2007), Burkina Faso (1993-2010) and Mexico (1995-1999).

\section{Conclusions}

Many research questions require that scholars use a discrete regime variable, either on the right- or left-hand side. Extant approaches to this task are laudable, but are often either limited in their temporal or geographical coverage, not fully transparent in their coding procedures, or have questionably low thresholds for democracy. None of them provide measures of measurement error or other sources of uncertainty to help identify ambiguous cases situated close to thresholds. In this article, we propose a new regime typology-RoW-covering almost all countries from 1900 to 2016 . We build on theory conceptualizing democracy as embodying the core value of making rulers responsive to citizens, achieved through electoral competition for the electorate's approval under circumstances when suffrage is extensive; political and civil society organizations operate freely; elections are clean and not marred by fraud or systematic irregularities; and where elections affect the chief executive of the country. In between elections, democracy requires freedom of expression and an independent media capable of presenting alternative views on matters of political importance. We hence classify countries only as democratic if a minimum level of Dahl's (1971) famous institutional requisites are fulfilled in terms of freedom of expression and alternative sources of information, freedom of association, universal suffrage, free and fair elections, and the degree to which power is de-facto vested in elected officials. Furthermore, we distinguish between democratic (liberal and electoral democracy) and autocratic subtypes (closed and electoral autocracy). Earlier versions of our typology have already been used in scholarly work on democratic backsliding (Mechkova et al., 2017b), the Sustainable Development Goals (Tosun \& Leininger, 2017), and political culture (Welzel, 2017), which further underscores the usefulness of the new RoW measures.

Our threshold for democracy is more demanding than in all extant data sets because we base our typology not only the existence and quality of elections but also on Dahl's notion of Polyarchy. Some extant data sets are limited to de-jure rules and other indicators that are directly observable. Other data sets only focus on the implementation of elections in a narrow sense, such as

\footnotetext{
17 Except for Freedom House (2017), which classifies Kenya as "Partly free" since 2002.
} 
their de-jure competitiveness. RoW is based on V-Dem's high standards in the aggregation of expert-coded data and recruitment of expert coders, which make the data more reliable and allows us to assess the de-facto implementation of institutions as opposed to simply their dejure existence.

Finally, RoW is the only measure of discrete regime types that explicitly addresses a fundamental challenge for all typologies: classifying political regimes involves some amount of measurement error and other sources of uncertainty. Therefore, we have designed RoW to incorporate V-Dem's Bayesian intervals indicating where $68 \%$ of the probability mass for each country-year score is located. We use these intervals to identify the cases which are close to the thresholds between categories and which are as a result ambiguously classified. Thus, the main RoW measure puts country-years in categories reflecting either certain regime types (closed dictatorships, electoral autocracies, electoral democracies, and liberal democracies), or ambiguous cases in lower and upper bounds of these regime types. This innovation opens up research avenues for incorporating such uncertainty in empirical analyses, thus avoiding biased and potentially misleading results.

\section{Acknowledgements}

We are grateful to Valeriya Mechkova for the idea of building a RoW typology capturing ambiguously classified cases. For helpful comments, we also thank Philip Keefer, Beth Simmons, Ariel I. Ahram, Josh Krusell, Kyle Marquardt, Rick Morgan, Dag Tanneberg, the editors and anonymous reviewers; and participants of the V-Dem Research Conference (May 2017), the APSA General Conference (August 2017), the Varieties of Autocracy workshop at the University of Gothenburg (June 2017; funded by Riksbankens Jubileumsfond) and the Empirical Study of Autocracy workshop at the University of Konstanz (September 2017) where earlier versions of this article was discussed. This research project was supported by Riksbankens Jubileumsfond, Grant M13-0559:1, PI: Staffan I. Lindberg, VDem Institute, University of Gothenburg, Sweden; by Knut and Alice Wallenberg Foundation to Wallenberg Academy Fellow Staffan I. Lindberg, Grant 2013.0166, V-Dem Institute, University of Gothenburg, Sweden; as well as by internal grants from the Vice-Chancellor's office, the Dean of the College of Social Sciences, and the Department of Political Science at University of Gothenburg.

\section{Conflict of Interests}

The authors declare no conflict of interests.

\section{References}

Abdulai, A.-G., \& Crawford, G. (2010). Consolidating democracy in Ghana: Progress and prospects? Democratization, 17(1), 26-67.
Abrahams, F. (1996). Human rights in post-communist Albania. New York, NY: Human Rights Watch.

Adcock, R., \& Collier, D. (2001). Measurement validity: A shared standard for qualitative and quantitative research. American Political Science Review, 95(3), 529-546.

Alvarez, M., Cheibub, J. A., Limongi, F., \& Przeworski, A. (1996). Classifying political regimes. Studies in Comparative International Development, 31(2), 3-36.

Bernhard, M., Hicken, A., Reenock, C. M., \& Lindberg, S. I. (2015). Institutional subsystems and the survival of democracy: Do political and civil society matter? (Working Paper (4)). Gothenburg: Varieties of Democracy Institute.

Bogaards, M. (2012). Where to draw the line? From degree to dichotomy in measures of democracy. Democratization, 19(4), 690-712.

Boix, C., Miller, M., \& Rosato, S. (2013). A complete data set of political regimes, 1800-2007. Comparative Political Studies, 46(12), 1523-1554.

Bollen, K. A., \& Jackman, R. W. (1989). Democracy, stability, and dichotomies. American Sociological Review, 54(4), 612-621.

Botero, J. C., \& Ponce, A. (2011). Measuring the rule of law (Working Paper Series). Washington, DC: The World Justice Project.

Brownlee, J. (2009). Harbinger of democracy: Competitive elections before the end of authoritarianism. In S. I. Lindberg (Ed.), Democratization by elections (Vol. 2009, pp. 128-47). Baltimore, MD: Johns Hopkins University Press.

Cheibub, J. A., Gandhi, J., \& Vreeland, J. R. (2010). Democracy and dictatorship revisited. Public Choice, 143(1/2), 67-101.

Cheibub, J. A., Przeworski, A., Limongi Neto, F. P., \& Alvarez, M. M. (1996). What makes democracies endure? Journal of Democracy, 7(1), 39-55.

Collier, D., \& Adcock, R. (1999). Democracy and dichotomies: A pragmatic approach to choices about concepts. Annual Review of Political Science, 2(1), 537-565.

Collier, D., \& Levitsky, S. (1997). Democracy with adjectives: Conceptual innovation in comparative research. World Politics, 49(3), 430-451.

Coppedge, M., Lindberg, S., Skaaning, S.-E., \& Teorell, J. (2016). Measuring high level democratic principles using the V-Dem data. International Political Science Review, 37(5), 580-593.

Coppedge, M., Gerring, J., Altman, D., Bernhard, M., Fish, S., Hicken, A., . . . Teorell, J. (2011). Conceptualizing and measuring democracy: A new approach. Perspectives on Politics, 9(2), 247-267.

Coppedge, M., Gerring, J., Lindberg, S. I., Skaaning, S.-E., Teorell, J., Altman, D., . . . Staton, J. (2017a). V-Dem codebook v7.1. Gothenburg: Varieties of Democracy (V-Dem) Project.

Coppedge, M., Gerring, J., Lindberg, S. I., Skaaning, S.-E., Teorell, J., Altman, D., . . W Wilson, S. (2017b). V-Dem 
[country-year/country-date] dataset v7.1. Gothenburg: Varieties of Democracy (V-Dem) Project.

Coppedge, M., Gerring, J., Lindberg, S. I., Skaaning, S.-E., Teorell, J., Krusell, J., . . . Wilson, S. (2017c). V-Dem methodology v7. Gothenburg: Varieties of Democracy (V-Dem) Project.

Coppedge, M., Gerring, J., Lindberg, S. I., Skaaning, S.E., \& Teorell, J. (2017d). V-Dem comparisons and contrasts with other measurement projects (Working Paper (45)). Gothenburg: Varieties of Democracy (V-Dem) Project.

Coulon, C. (1988). Senegal: The development and fragility of semidemocracy. Democracy in Developing Countries, 2, 141-178.

Dahl, R. A. (1956). A preface to democratic theory. Chicago, IL: University of Chicago Press.

Dahl, R. A. (1971). Polyarchy: Participation and opposition. New Haven, CT: Yale University Press.

Dahl, R. A. (1998). On democracy. New Haven, CT: Yale University Press.

Diamond, L. (1999). Developing democracy: Toward consolidation. Baltimore, MD: Johns Hopkins University Press.

Diamond, L. (2002). Thinking about hybrid regimes. Journal of Democracy, 13(2), 21-35.

Donno, D. (2013). Elections and democratization in authoritarian regimes. American Journal of Political Science, 57(3), 703-716.

Erdmann, G. (2011). Decline of democracy: Loss of quality, hybridisation and breakdown of democracy. In G. Erdmann \& M. Kneuer (Eds.), Regression of democracy? (pp. 21-58). Wiesbaden: Springer.

Freedom House. (2017). Freedom in the world 2016. Washington, DC: Freedom House.

Gandhi, J., \& Lust-Okar, E. (2009). Elections under authoritarianism. Annual Review of Political Science, 12, 403-422.

Geddes, B., Wright, J., \& Frantz, E. (2014). Autocratic breakdown and regime transitions: A new data set. Perspectives on Politics, 12(2), 313-331.

Geddes, B., Wright, J., \& Frantz, E. (2013). Autocratic regimes code book, version 1.2. Perspective on Politics, 12(2). Retrieved from http://sites.psu.edu/ dictators/wp-content/uploads/sites/12570/2014/06 /GWF-Codebook.pdf

Gleditsch, K. S., \& Ward, M. D. (2006). Diffusion and the international context of democratization. International Organization, 60(4), 911-933.

Goertz, G. (2006). Social science concepts: A user's guide. Princeton, NJ: Princeton University Press.

Hamilton, A., Madison, J., \& Jay, J. (2009). The federalist papers. New York, NY: Palgrave Macmillan. (Original work published 1787)

Harris, D. J. (2014). Sierra Leone: A political history. Oxford: Oxford University Press.

Human Rights Watch. (2008). Ballots to bullets: Organized political violence and Kenya's crisis of governance. New York, NY: Human Rights Watch.
Huntington, S. P. (1992). The third wave: Democratization in the late twentieth century. Norman, OK: University of Oklahoma Press.

Kagwanja, P., \& Southall, R. (2009). Kenya's uncertain democracy: The electoral crisis of 2008. Journal of Contemporary African Studies, 27(3), 257-461.

Kailitz, S. (2013). Classifying political regimes revisited: Legitimation and durability. Democratization, 20(1), 39-60.

Karl, T. (1986). Imposing consent? Electoralism versus democratization in El Salvador. In P. Drake \& E. Silva (Eds.), Elections and democratization in Latin America (pp. 9-36). San Diego, CA: University of California San Diego.

Kelley, J. (2009). D-minus elections: The politics and norms of international election observation. International Organization, 63(4), 765-787.

Knutsen, C. H., \& Wig, T. (2015). Government turnover and the effects of regime type: How requiring alternation in power biases against the estimated economic benefits of democracy. Comparative Political Studies, 48(7), 882-914.

Levitsky, S., \& Way, L. A. (2010). Competitive authoritarianism: Hybrid regimes after the cold war. Cambridge: Cambridge University Press.

Lewis, P. M. (2011). Nigeria votes: More openness, more conflict. Journal of Democracy, 22(4), 60-74.

Lindberg, S. I. (2006). Democracy and elections in Africa. Baltimore, MD: Johns Hopkins University Press.

Lindberg, S. I. (2016). Ordinal versions of V-Dem's indices: When interval measures are not useful for classification, description, and sequencing analysis purposes. Geopolitics, History, and International Relations, 8(2), 76-111.

Lindberg, S. I., Coppedge, M., Gerring, J., \& Teorell, J. (2014). V-Dem: A new way to measure democracy. Journal of Democracy, 25(3), 159-169.

Lührmann, A., McMann, K. M., \& Van Ham, C. (2017). The effectiveness of democracy aid to different regime types and democracy sectors (Working Paper (40)). Gothenburg: Varieties of Democracy Institute.

Marquardt, K. L., \& Pemstein, D. (2017). IRT models for expert-coded panel data (Working Paper (41)). Gothenburg: Varieties of Democracy Institute.

Marshall, M. G., Gurr, R. T., \& Jaggers, K. (2014). Political regime characteristics and transitions, 18002015. Data set users' manual. Vienna, VA: Center for Systemic Peace.

Mechkova, V., Lührmann, A., \& Lindberg, S. I. (2017a). From de-jure to de-facto: Mapping dimensions and sequences of accountability (World Development Report 2017). Washington, DC: World Bank.

Mechkova, V., Lührmann, A., \& Lindberg, S. I. (2017b). How much democratic backsliding? Journal of Democracy, 28(4), 162-169.

Merkel, W. (2004). Embedded and defective democracies. Democratization, 11(5), 33-58.

Munck, G. L. (2009). Measuring democracy: A bridge be- 
tween scholarship and politics. Baltimore, MD: Johns Hopkins University Press.

Organization of American States. (2008). Hemispheric struggle for women's suffrage, Inter-American Commission on Women Organization of American States. Retrieved from www.oas.org

Pastor, R. A. (1999). The third dimension of accountability: The international community in national elections. In A. Schedler (Ed.), The self-restraining state: Power and accountability in new democracies (pp. 123-142). Boulder, CO: Lynne Rienner Publishers.

Pemstein, D., Marquardt, K. L., Tzelgov, E., Wang, Y.-T., Krusel, J., \& Miri, F. (2017). The V-Dem measurement model: Latent variable analysis for cross-national and cross-temporal expert-coded data (Working Paper (21)). Gothenburg: Varieties of Democracy Institute.

Przeworski, A., Alvarez, M. E., Cheibub, J. A., \& Limongi, F. (2000). Democracy and development: Political institutions and well-being in the world, 1950-1990 (Vol. 3). Cambridge: Cambridge University Press.

Rössler, P. G., \& Howard, M. M. (2009). Post-cold war political regimes: When do elections matter? In $\mathrm{S}$. I. Lindberg (Ed.), Democratization by elections (Vol. 2009, pp. 101-128). Baltimore, MD: Johns Hopkins University Press.

Rutten, M., \& Owuor, S. (2009). Weapons of mass destruction: Land, ethnicity and the 2007 elections in Kenya. Journal of Contemporary African Studies, 27(3), 305-324.

Sartori, G. (1970). Concept misformation in comparative politics. American Political Science Review, 64(4), 1033-1053.

Schedler, A. (2002). The menu of manipulation. Journal of Democracy, 13(2), 36-50.

Schedler, A. (2006). Electoral authoritarianism: The dynamics of unfree competition. Boulder, CO: Lynne Rienner Publishers.

Schedler, A. (2013). The politics of uncertainty: Sustain- ing and subverting electoral authoritarianism. Oxford: Oxford University Press.

Svolik, M. (2008). Authoritarian reversals and democratic consolidation. American Political Science Review, 102(2), 153-168.

Tosun, J., \& Leininger, J. (2017). Governing the Interlinkages between the Sustainable Development Goals: Approaches to attain policy integration. Global Challenges, 1(9), 1-12.

Turner, M., \& Tshering, J. (2014). Is democracy being consolidated in Bhutan? Asian Politics \& Policy, 6(3), 413-431.

Vanhanen, T. (2005). Measures of democracy 1810-2004. Version, 2., Dataset. Tampere: Finnish Social Science Data Archive.

Vengroff, R. (1993). Transition to democracy in Senegal: The role of decentralization. In I. Kim \& J. Shapiro (Eds.), Establishing democratic rule (pp. 159-188). Washington, DC: Paragon Press.

Wahman, M. (2014). Democratization and electoral turnovers in Sub-Saharan Africa and beyond. Democratization, 21(2), 220-243.

Wahman, M., Teorell, J., \& Hadenius, A. (2013). Authoritarian regime types revisited: Updated data in comparative perspective. Contemporary Politics, 19(1), 19-34.

Wang, Y.-T., Lindenfors, P., Sundstöm, A., Jansson, F., Paxton, P., \& Lindberg, S. I. (2017). Women's rights in democratic transitions: A global sequence analysis, 1900-2012. European Journal of Political Research, 56(4), 735-756.

Welzel, C. (2013). Freedom rising: Human empowerment and the quest for emancipation. Cambridge: Cambridge University Press.

Welzel, C. (2017). A tale of culture-bound regime evolution: The centennial democratic trend and its recent reversal (Users Working Paper (11)). Gothenburg: Varieties of Democracy (V-Dem) Project.

\section{About the Authors}

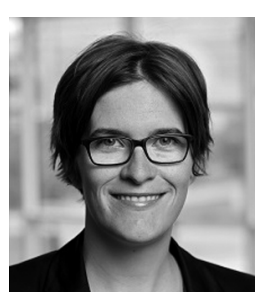

Anna Lührmann is a Senior Research Fellow at the Varieties of Democracy (V-Dem) Institute (University of Gothenburg). She received her PhD in 2015 from Humboldt University (Berlin). Her articles on regime change, autocracies, democracy aid, and elections have appeared in the Journal of Democracy, Electoral Studies, and International Political Science Review.

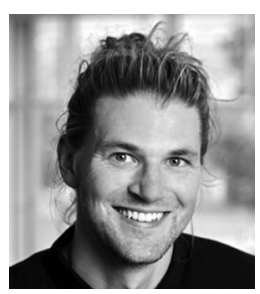

Marcus Tannenberg is a PhD candidate at the Varieties of Democracy (V-Dem) Institute at the department of political science, University of Gothenburg. Marcus's work focuses on politics and public opinion in autocratic regimes, and survey methodology. 


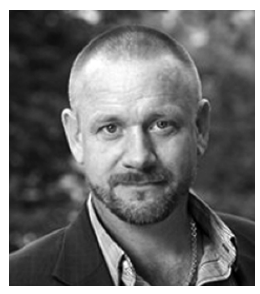

Staffan I. Lindberg is the director of the Varieties of Democracy (V-Dem) Institute and Professor of Political Science at the University of Gothenburg. He is a Wallenberg Academy Scholar, a member of the Young Academy of Sweden and recipient of an ERC consolidator grant as well as numerous other grants and awards for his research. He is the author of Democracy and Elections in Africa (John Hopkins University Press, 2006) and editor of Democratization by Elections (John Hopkins University Press, 2009). 


\section{Appendix}

\section{Threshold between Closed and Electoral Autocracies in Detail}

The V-Dem data set includes specific indicators for legislative and executive elections (v2elmulpar_osp_leg/v2elmulpar_ osp_ex). To identify which of the two should be used for assessing if the Head of the Executive is subject to de-jure multiparty elections, we need to take the relative power of the Head of State (HoS) and the Head of Government (HoG) and the appointment procedures into account. The V-Dem variable v2ex_hosw identifies if the HoS (v2ex_hosw $=1$ ) or HoG ( $\left.v 2 e x \_h o s w<1\right)$ is the chief executive. If the HoG is the chief executive, the variable v2expathhg indicates whether the HoG is directly (8) or indirectly (7) elected or appointed by the HoS (6). In the first case, we take the multiparty variable for executive elections (v2elmulpar_osp_ex), in the second case for legislative elections (v2elmulpar_osp_leg) and in the third case the score for HoS as follows. If the HoS is the chief executive, the variable v2expathhs indicates whether the HoS is directly (7) or indirectly (6) elected. In the first case, we take the multiparty variable for executive elections (v2elmulpar_osp_ex), in the second case for legislative elections (v2elmulpar_osp_leg). (see Coppedge et al., 2017a).

\section{RoW by Country for 2016.}

\begin{tabular}{|c|c|c|c|c|c|c|c|}
\hline \multirow{2}{*}{$\begin{array}{l}\text { Liberal Democracy } \\
\text { Albania }\end{array}$} & & \multicolumn{2}{|l|}{ Electoral Democracy } & \multicolumn{2}{|l|}{ Electoral Autocracy } & \multicolumn{2}{|l|}{ Closed Autocracy } \\
\hline & & Bhutan & + & Comoros & + & Turkmenistan & + \\
\hline Australia & & Cape Verde & + & Fiji & + & Kuwait & + \\
\hline Austria & & Chile & + & Guinea & + & Vietnam & + \\
\hline Belgium & & Ghana & + & Haiti & + & & \\
\hline Canada & & Guyana & + & Honduras & + & China & \\
\hline Costa Rica & & Israel & + & Iraq & + & Cuba & \\
\hline Cyprus & & Lithuania & + & Madagascar & + & Eritrea & \\
\hline Denmark & & Mauritius & + & Mozambique & + & Jordan & \\
\hline Estonia & & Moldova & + & Niger & + & Laos & \\
\hline Finland & & Panama & + & Papua New Guinea & + & Libya & \\
\hline France & & Poland & + & Serbia & + & Morocco & \\
\hline Germany & & Senegal & + & Somaliland & + & North Korea & \\
\hline Iceland & & Seychelles & + & & & Oman & \\
\hline Ireland & & Slovakia & + & Afghanistan & & Palestine/Gaza & \\
\hline Japan & & South Africa & + & Algeria & & Qatar & \\
\hline Netherlands & & São Tomé \& Príncipe & + & Angola & & Saudi Arabia & \\
\hline New Zealand & & Trinidad \& Tobago & + & Armenia & & Somalia & \\
\hline Norway & & Tunisia & + & Azerbaijan & & South Sudan & \\
\hline Portugal & & Vanuatu & + & Bangladesh & & Swaziland & \\
\hline Spain & & & & Belarus & & Syria & \\
\hline Sweden & & Argentina & & Bosnia \& Herzegovina & & Thailand & \\
\hline Switzerland & & Bolivia & & Burma/Myanmar & & Yemen & \\
\hline United Kingdom & & Brazil & & Burundi & & & \\
\hline United States & & Bulgaria & & Cambodia & & & \\
\hline Uruguay & & Burkina Faso & & Cameroon & & & \\
\hline & & Colombia & & Chad & & & \\
\hline Barbados & - & Croatia & & Dem. Rep. of Congo & & & \\
\hline Benin & - & Dominican Rep & & Djibouti & & & \\
\hline Botswana & - & Ecuador & & Egypt & & & \\
\hline Czech Republic & - & El Salvador & & Equatorial Guinea & & & \\
\hline Italy & - & Georgia & & Ethiopia & & & \\
\hline Latvia & - & Greece & & Gabon & & & \\
\hline Namibia & - & Guatemala & & Gambia & & & \\
\hline Slovenia & - & Hungary & & Iran & & & \\
\hline South Korea & - & India & & Kazakhstan & & & \\
\hline Taiwan & - & Indonesia & & Malaysia & & & \\
\hline & & Ivory Coast & & Maldives & & & \\
\hline & & Jamaica & & Mauritania & & & \\
\hline
\end{tabular}




\begin{tabular}{|c|c|c|c|c|}
\hline \multirow{2}{*}{ Liberal Democracy } & \multicolumn{2}{|l|}{ Electoral Democracy } & Electoral Autocracy & \multirow[t]{2}{*}{ Closed Autocracy } \\
\hline & Lesotho & & Montenegro & \\
\hline & Liberia & & Nicaragua & \\
\hline & Mali & & Pakistan & \\
\hline & Mexico & & Palestine/West Bank & \\
\hline & Mongolia & & Rep. of the Congo & \\
\hline & Nepal & & Russia & \\
\hline & Nigeria & & Rwanda & \\
\hline & Paraguay & & Singapore & \\
\hline & Peru & & Sudan & \\
\hline & Philippines & & Tajikistan & \\
\hline & Romania & & Tanzania & \\
\hline & Solomon Islands & & Turkey & \\
\hline & Sri Lanka & & Uganda & \\
\hline & Suriname & & Ukraine & \\
\hline & Timor-Leste & & Venezuela & \\
\hline & Togo & & Zambia & \\
\hline & & & Zanzibar & \\
\hline & Central African Rep. & - & Zimbabwe & \\
\hline & Guinea-Bissau & - & & \\
\hline & Kenya & - & Uzbekistan & - \\
\hline & Kosovo & - & & \\
\hline & Kyrgyzstan & - & & \\
\hline & Lebanon & - & & \\
\hline & Macedonia & - & & \\
\hline & Malawi & - & & \\
\hline & Sierra Leone & - & & \\
\hline
\end{tabular}

Note: The "+" and "-" denotes an ambiguous case. "+" indicates that some evidence suggests that the country might be better placed in the next higher category. "-" indicates that the country might be better placed in the next lower category. For more detail see section 3.

\section{References}

Coppedge, M., Gerring, J., Lindberg, S. I., Skaaning, S.-E., Teorell, J., Altman, D., . . Staton, J. (2017a). V-Dem codebook v7.1. Gothenburg: Varieties of Democracy (V-Dem) Project. 